\title{
Waste Management Scenario through Community Based Waste Bank: A Case Study of Kepanjen District, Malang Regency, Indonesia
}

\author{
Hasfarm D. Purba, Christia Meidiana, and Dimas W. Adrianto
}

\begin{abstract}
The population growth in Kepanjen District leads to the waste volume increase. Due to the fact that the landfill in this area is approaching its maximum capacity, the local government needs to find out other alternatives to treat the waste. This article proposes one sort of solutions to prolong the landfill's age through waste minimization involving community participation. Therefore, waste reduction through waste bank has been initiated in Kepanjen District. The primary survey in form of deep interview with related stakeholders has been conducted to gain the data used for community participation analysis. The output of community participation analysis is the level of community participation. The assessment of participation level is used five indicators of participation rate determined by local government. Afterwards, scenario approach is used. The scenario is made based on the level of participation in Kepanjen District. The result showed that Kepanjen District has three kind of participation rate which are low, medium, and high participation. Consequently, the scenarios proposed are pessimist scenario, fair scenario, and optimist scenario for low, medium, and high participation respectively. Pessimist scenario focuses on avoiding the community to do open burning causing air pollution and health injury. Meanwhile, the fair scenario starts to introduce the institution to the community to conduct the capacity building of the community in waste separation. The optimist scenario proposes the implementation of waste bank involving the community.
\end{abstract}

Index Terms-Waste Bank, community participation, waste management scenario.

\section{INTRODUCTION}

Regional growth and development give significant impact on several development aspects including the environment. Population activities and consumptions in urban and rural area have influence on waste increase. The solid waste from households becomes problems of the community and government. The increasing volume of the garbage was not balance with the waste management program. Still many communities manage their garbage traditionally and do not consider the impact on the environment. Besides, the lack of financial viability for the waste management gives the impact on sustainability of the waste management programs [1]. Malang Regency is one of the regions in Indonesia facing this problem. Malang Regency has population growth about $0.89 \%$ each year [2]. It leads to increase of waste volume and waste management costs. As Kepanjen District is the capital

Manuscript received July 31, 2013; revised October 3, 2013.

The authors are with the Department of Urban and Regional Planning, Brawijaya University, Malang, East Java, Indonesia (e-mail: hasfarmdianpurba@ymail.com, c_meideiana@ub.ac.id, dimas_adrianto@yahoo.com). of Malang Regency, there is a significant development of its urban area. The development in housing sector affects the growth of industry as it provides employment for the people, and vice versa. The waste generation increases as it is proportional to the population growth [3]. As household is the main source of solid waste in Malang regency, the waste is characterized by high organic waste. However, fraction of recyclable waste such as paper, plastic, metals and glass can be considered. The management of this recyclable waste is potentials as it can contribute to waste reduction and income increase [4]. Yet, the community should involve in waste management. Based on the waste law No. 18/2008 and the government regulation No. $81 / 2012$, there are some needs to change the recent paradigm [5]. The paradigm in collecting-carrying-dumping should be changed to be reduction of waste from the source [6]. One of the alternative solutions is to involve the community to reduce waste by implementing waste bank effectively. The household as the waste producer can claim payment as an exchange of the waste deposited in the waste bank. The community participation is the point for developing the waste bank program in decreasing the waste volume in Kepanjen District. The waste bank is mainly addressed to motivate the community to separate the waste, give the reward for efforts in separating, and collecting waste in form of monetary instrument. Furthermore, the age of landfill can be prolonged by waste bank. It helps the local government to allocate their financial to other waste management program. As the developing area, Kepanjen District has the power in community participation. In majority, people work as the farmer. It looks that Kepanjen District still have many agriculture areas. This is potent to improve the waste bank.

\section{RESEARCH METHODOLOGY}

Primary and secondary survey is used for collecting data in this research. The primary survey is conducted to obtain primary data which aims to determine the characteristics of the people in the Kepanjen District. Primary data collection techniques used in this study is open-ended interview and observation. The interviewees are the representative of local government, key person in the area of study, the expert in the field, and the scavengers. The observation has been done for two weeks to observe the current practices of waste separation in the community. The secondary survey is conducted by recording the documents obtained from the local government related to waste management such as population data and national standard of waste generation per capita. Waste generation per capita is assumed to be equal to 
the national standard since there is no data on waste generation per capita in local government. The product of waste generation per capita and number of population is the total volume of generated waste in Kepanjen District. Review on related regulation and policy was conducted as well as study on related literature to support the identification of community involvement in waste management in Kepanjen District. The participation rate is assessed using five indicators of participation rate determined by the local government. The rate is classified into three which are low, medium, and high participation. Table I describes the classification of participation.

TABLE I: THE RATE OF PARTICIPATION ClASSIFICATION

\begin{tabular}{lll}
\hline \hline The Indicators & Low & Medium \\
\hline Mutual Aid & & \\
\hline Participation in & \\
Event & \\
\hline Join With & \\
Community & \\
\hline Supporting in & \\
Community & \\
\hline Government \\
Supporting
\end{tabular}

The scenarios are determined based on the results of participation rate assessment and local condition representing low, medium, and high rate of participation. This scenario is named path scenario method [7]. It looks the existing condition and makes the plan and strategy to waste management in the future.

\section{RESULT AND DISCUSSION}

\section{A. Area of Study}

Kepanjen District is the area of study covering the area of 4030.88 ha with population of 96,675 people. Kepanjen District has climate type $\mathrm{C}$ which is tropical with 7 wet months and 5 dry months. The average daily temperature is $32^{\circ}-34^{\circ} \mathrm{C}$ for the maximum temperature and $26^{\circ}-28^{\circ} \mathrm{C}$ for the minimum temperature. The average precipitation is $2,100 \mathrm{~mm}$ per year with annual rainy days is 170 [8]. The district belongs to the Malang Regency having the highest number of population and the most rapid population growth. The annual population growth is $0.89 \%$ giving the impact on waste domestic volume increase. The area is unique because it is transforming from sub urban to urban area caused by its function as the capital of regency. Therefore, it develops relative fast. Fig. 1 shows the population growth in Kepanjen District from 2004 until 2012.

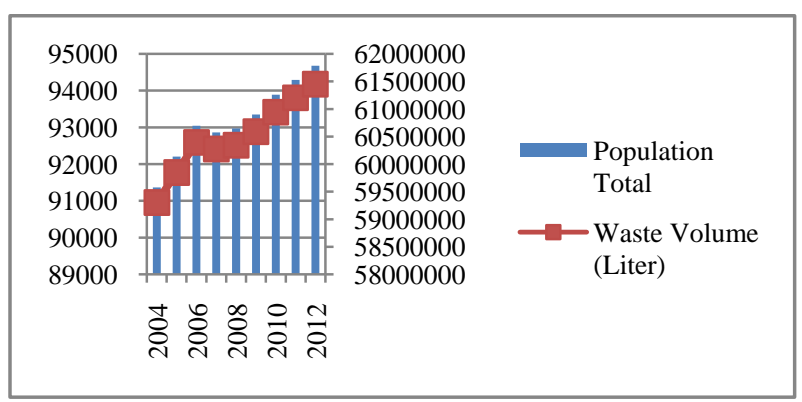

Fig. 1. Waste generation in Kepanjen district.
Generally, the population tends to increase from 2004 until to 2012 although there was decrease in 2006. Kepanjen Village as the centre of Kepanjen District has the highest population than other villages. Until 2012 year, the total of population in Kepanjen Village is 11,486 people followed by Panggungrejo Village and Talangagung Village with the population of 7,390 people and 7260 people respectively. The figure shows that waste generation is proportional to the population growth. The change of lifestyle, living standard, and pattern of consumption form sub urban to urban area community are the factors. Besides, due to the development of employment, many people from the surrounding villages and districts immigrate to this district to find job. Waste becomes the problem in environmental and health sector. The waste management in Kepanjen District is characterized by typical condition as in Indonesian cities. The waste is dominated by organic waste (more $70 \%$ ) because the waste source is mainly from household (43.4\%) [9]. Furthermore, the lack of finance leads to inferior condition of waste management. Table II shows the general condition of soild waste management in Kepanjen District.

TABLE II: The SALIENT FEATURE of WASte MANAGEMENT IN KePANJEN DISTRICT

\begin{tabular}{lcc}
\hline \hline \multicolumn{1}{c}{ Parameter } & Unit & Kepanjen District \\
\hline Area & Ha & 4030.88 \\
\hline Population & People & 96,675 \\
\hline Waste total & Liter per year & $60,483,654$ \\
\hline Waste generation per capita & Liter per day & 7.21 \\
\hline \hline
\end{tabular}

Though the waste composition is dominated by the organic waste, there are significant fractions of recyclable waste. Table III shows the detail of the composition recyclable waste.

TABLE III: THE Fraction FEATURE OF WASTE MANAGEMENT IN KEPANJEN DISTRICT

\begin{tabular}{|c|c|c|c|}
\hline Composition & Unit & Waste Volume & $\begin{array}{c}\text { Percentage } \\
(\%)\end{array}$ \\
\hline Paper & \multirow{4}{*}{$\begin{array}{l}\text { Liters per year } \\
\text { (In Thousands) }\end{array}$} & 3,749 & 6.05 \\
\hline Plastic & & 9,495 & 15.31 \\
\hline Metal & & 362 & 0.58 \\
\hline Glass & & 120 & 0.19 \\
\hline
\end{tabular}

Meanwhile, Table III shows the waste composition in Malang Regency assumed to be the same as in Kepanjen District.

\section{B. Waste Bank}

The increasing volume of the garbage was not balance with the waste management program. Still many communities manage their garbage traditionally and do not consider the impact on the environment [10]. The lack of government's ability to finance the waste management reduces the sustainability of the waste management programs [11].

Today, the capital owned by Malang Regency to overcome the waste problem is the social capital in the community. The social capital is the informal values in community to reach collective goals. The informal values become the adhesive that will keep the cohesiveness of the group members collectively. It can be used as opportunity to involve the community in overcoming the waste problem through waste bank program. 
According to the regulation of Ministry of Environment 13/2012 about the implementation guideline of reduce, reuse, and recycle through waste bank, the definition of waste bank is a place to sort and collect the garbage that can be recycled and/or reused that have economic values [5]. The waste bank development is the community innovative activities that teach the community to sort their garbage and make them aware on managing their garbage wisely. It will bring contribution in the garbage volume reduction. The main principle of the waste bank development is involving and empowering the community [12]. The waste bank development as the solution for waste problem begins with the community's concern about the environmental degradation.

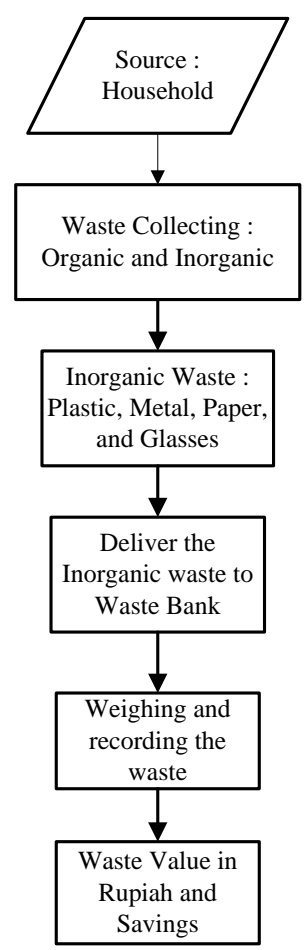

Source: MoI 13/2012

Fig. 2.The mechanism of waste bank.

Fig. 2 shows the mechanism of waste bank in waste management. The mixed waste from household is not giving the value for recyclable waste (plastic, metal, paper, and glass). Waste bank activity is not only savings but empowering the community to manage the waste. Empowerment is in the form of skills training to reduce, utilize, and recycle the waste into a product that has more value. Kepanjen District community as actor in this program can increase their income by collecting waste. By applying this pattern, we expect that the waste volume disposed to landfill will be reduced. In addition, the waste bank program can also support Kepanjen District government policy in achieving zero waste programs in the future.

\section{Waste Management Scenario}

The waste management program unfortunately was unable to accommodate the increasing waste volume. Hence, most of the community still conduct the traditional method of waste management and do not consider environment quality. The increasing waste volume was not balanced with the capacity of waste management program [12]. Beside, the lack of finance for the waste management impacts the sustainability of the waste management programs. The waste bank development is the community innovative activities that give to the community lesson to learn their waste and make them aware on managing their garbage. It will bring contribution on waste reduction in landfill. The main principle of the waste bank development is involving and empowering the community. The waste bank development as the solution for waste problem is initiated with the increasing community's awareness on environmental degradation.

Waste Bank can act as dropping point for the community to throw away the waste and for the producer to take the recyclable materials as input for further production process. Through waste bank the community as an actor can increase their awareness on environmental problem, support building capacity, and income as well. In long term waste bank can reduce the waste disposed of in landfill. Community participation in Kepanjen District is assessed from participation in formal or informal organizations activity. The organization accommodates the involvement of non-governmental agencies interested in waste management. The rate of participation in Kepanjen District based on socio-cultural indicators of community [8] is described in Table IV.

TABLE IV: THE RATE OF PARTICIPATION CLASSIFICATION

\begin{tabular}{lccc}
\hline \hline The Indicators & Low & Medium & High \\
\hline Mutual Aid & + & + & + \\
\hline Participation in Event & + & + & + \\
\hline Join With Community & - & + & + \\
\hline $\begin{array}{l}\text { Supporting in } \\
\text { Community }\end{array}$ & - & - & + \\
\hline Government Supporting & - & + & + \\
\hline \hline
\end{tabular}

Kepanjen District consists of low participation, medium participation, and high participation. It affirms the opinion propose by [13] that community participation in waste management in developing country differs from developed country. Generally, the community participation in developing country is higher than developed country. It can be assumed that the rate of participation is related high. However, there is the existence of low and medium participation. Therefore, three kind of scenario are proposed for each type of participation.

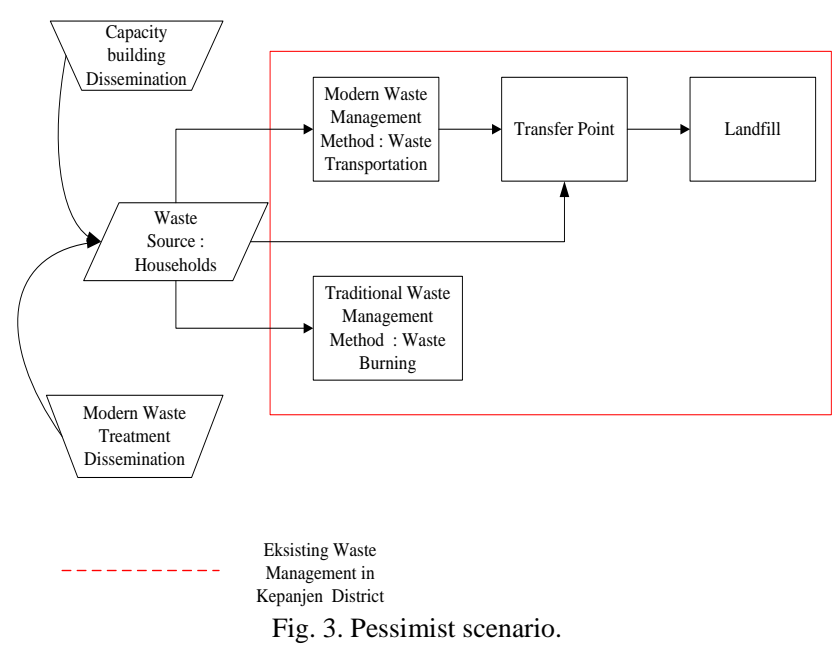

Fig. 3 shows the pessimist scenario that there is an 
intervention on waste generation which is dissemination about capacity building and modern waste treatment. Capacity building will open community's mind in waste problem. This is the first step to improve community participation in environmental activities related to institutional and waste management. Traditional method of waste management is not effective for waste reduction. Burning the waste will increase the air pollution in environment

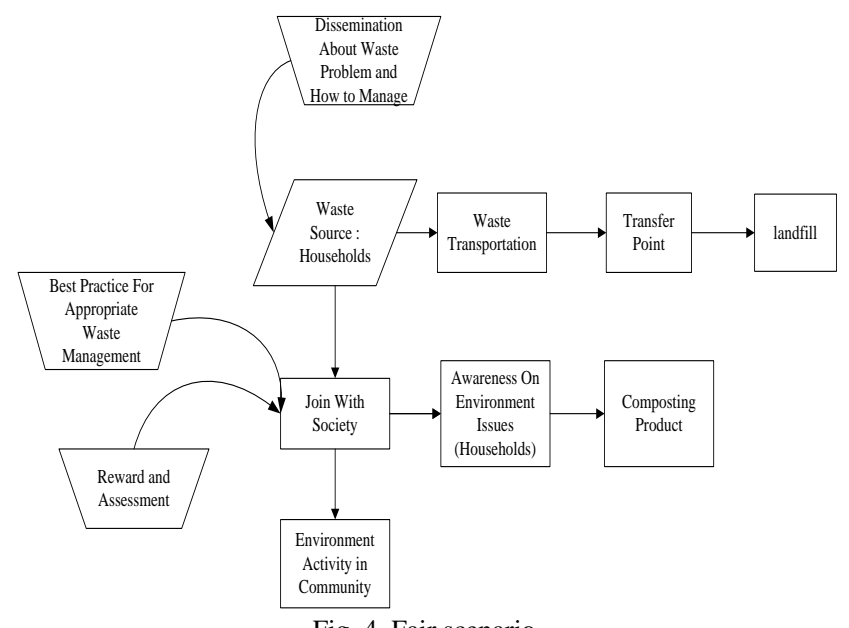

Fig .4. Fair scenario.

Fig. 4 shows fair scenario. The fair scenario starts to introduce the group/society to the community in order to conduct the capacity building of the community in waste separation. The community will give contribution in the group activity. The main point in this scenario is increasing the awareness of community on environment issues. Household as the source of waste will be the object for this scenario. In other side, the intervention to community is begun compared study of best waste management and giving the reward and assessment. The reward and assessment given to community is the incentive for their activity in household waste management.

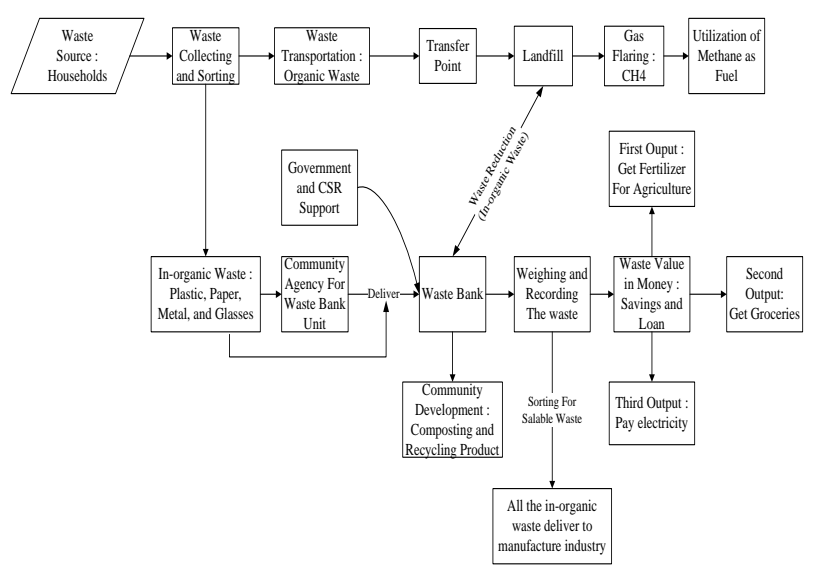

Fig. 5. Optimist scenario.

Fig. 5 shows the optimist scenario proposing the implementation of waste bank involving the community. The high participation explains that the community is able to give contribution and awareness on waste problem. The community will get the impact in economy, education, health, and environment. The waste bank is main point these scenario. The participation in Kepanjen District community is high, so optimist scenario can implement in this area. Kepanjen District will have three main outputs. The first output is getting the fertilizer for agriculture. It helps the farmer to fill their desires in farm activity. The second output is getting foodstuff and the last program is paying the electricity. The third output from these scenarios will give the contribution for community life and government in Kepanjen District.

\section{CONCLUSIONS}

Waste bank is the solution to managing the waste with community participation. Community based waste bank will give the contribution in waste problem in developing country. The community is able to utilize the waste as the goods having value things. The result of community participation analysis shows that Kepanjen has three rate of participation. They are low participation, medium participation, and high participation. The optimist scenario in waste management can be implementing if the community in the study area have high participation.

Based on the research, Kepanjen District has three scenarios from community participation analysis. They are pessimist scenario, fair scenario, and optimist scenario. In majority, Kepanjen District has high participation. The scenario which implement in this area is optimist scenario. The waste bank development as the solution for waste problem begins with the community awareness to environment issues. Social capital, creative idea, and governmental support have become a unity in managing the waste through waste bank. The merits of the community based waste bank in Kepanjen District are follows: environment, social, education, and economic aspect.

\section{RECOMMENDATIONS}

Waste bank is one of many waste management programs which can be implemented in developing country such as Indonesia. The inadequate capability of local government to manage the waste can be reduced using this program. However, some improvement should be further observed and implemented. The improvement of waste information system, coordination among related sectors and program dissemination as well as payment system in waste bank should be continually conducted. Further study related in economic analysis of waste bank can be conducted in order to measure exactly the benefit can be attained by involving the community in separating waste through waste bank

\section{ACKNOWLEDGMENT}

The authors would like to express their intense appreciation and deepest gratitude to Urban and Regional Planning of Brawijaya University and Malang Regency Government for their important contributions to the development of this work.

\section{REFERENCES}

[1] C. Meidiana and T. Gamse, "The new law: Challenging opportunity for FUTURE landfill operation in Indonesia," Waste Management Research Journal. , SAGE Publishing, pp. 20-29, vol. 29, no.1, 2011. 
[2] BPS (Badan Pusat Statistik), Statistical Pocketbook of Indonesia, 2012

[3] C. Meidiana and T. Gamse, "Waste Management Practices in Indonesia," European Journal of Scientific Research., pp. 199-210, vol. 40, no. 2, EuroJournals Publishing Inc, 2010.

[4] Ministry of Environment, Indonesia Waste Bank Profile, 2012.

[5] Ministry of Environment, Guideline of Reduce, Reuse, and Recycle through Waste Bank No. 13/2012, Jakarta, 2012.

[6] Ministry of Environment, Waste Management Act No. 18/2008, Jakarta, 2008.

[7] E. Wollenberg, D. Edmunds, and L. Buck, Mengantisipasi Perubahan: Skenario Sebagai Sarana Pengelolaan Hutan Secara Adaptif, Bogor : SMK Grafika Desa Putera, 2001, ch. 3, pp. 27-28.

[8] Spatial Planning Agency of Malang Regency, Detail Spatial Planning Document of Kepanjen District, 2012.

[9] C. Meidiana, Scenarios for Sustainable Final Waste Treatment in Developing Country, INTECH, ch. 11, pp. 227-256.

[10] N. Ejaz and M. S. Janjua, "Solid Waste Management Issue in Small Towns of Developing World: A Case Study of Taxila City," International Journal of Environmental Science and Development, vol. 3, no. 2, April 2012.
[11] Ministry of Environment, Bank Sampah dan 3R: Membangun Lingkungan dan Ekonomi Rakyat, 2011.

[12] B. Suwerda, Bank Sampah (Kajian Teori dan Penerapan), Yogyakarta: Pustaka Rihama, 2012.

[13] Japan International Coorperation Agency, Supporting Capacity Development for Solid Waste Management in Developing Countrie : Toward Improving Solid Waste Management Capacity of Entire Society, 2005.

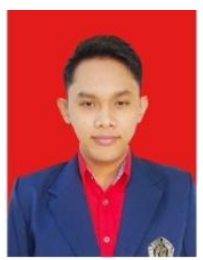

Hasfarm D. Purba was born on May 17 in Medan, Indonesia. $\mathrm{He}$ is studying undergraduate in Brawijaya University majoring in Urban and Regional Planning. The university stays in Malang, East Java, Indonesia. He has study in there since 2010 until now. He is an assistant of rural planning laboratory. He has interesting in policy analysis, rural planning, environment management, and waste management. Currently, the author is doing actively research related to community development and waste management. 